\section{Case Reports in Neurology}

Case Rep Neurol 2020;12:104-105

DOI: 10.1159/000509858

Published online: December 14, 2020 (c) 2020 The Author(s)

Published by S. Karger AG Basel D OPEN www.karger.com/crn

This article is licensed under the Creative Commons Attribution-NonCommercial 4.0 International License (CC BY-NC) (http://www.karger.com/Services/OpenAccessLicense). Usage and distribution for commercial purposes requires written permission.

\title{
Stroke in Asia: Neurosonology in Neurocritical Care
}

\author{
Deepak Arjundas $^{\mathrm{a}} \quad$ Jeyaraj Durai Pandian ${ }^{\mathrm{b}}$ Kay Sin Tan ${ }^{\mathrm{c}}$ \\ Narayanaswamy Venketasubramanian ${ }^{d}$ \\ a Department of Neurology, Vijaya Hospital and Mercury Nursing Home, Chennai, India; \\ ${ }^{b}$ Department of Neurology, Christian Medical College, Ludhiana, India; 'Division of \\ Neurology, Department of Medicine, University of Malaya, Kuala Lumpur, Malaysia; \\ dRaffles Neuroscience Centre, Raffles Hospital, Singapore, Singapore
}

\section{Keywords \\ Stroke · Asia · Case reports · Neurosonology}

Neurosonology is an important non-invasive technology using ultrasound to diagnose cerebrovascular arterial diseases and to monitor cerebral hemodynamics. It has a variety of clinical bedside applications. There are four interesting cases in this section, which proves the utility of neurosonology in neurocritical care. The first case was a patient with bacterial meningitis and cerebral vasculopathy where transcranial Doppler showed improvement in mean flow velocity following treatment with antibiotics [1].

Another important utility of transcranial Doppler was the monitoring of vasospasm in subarachnoid hemorrhage, which was described in the second patient [2]. In the third patient, using transcranial color-coded duplex ultrasound in a novel manner, the cerebrovascular reserve was assessed in dissection involving the right middle cerebral artery with hemodynamic vascular symptoms [3]. In the fourth patient, transcranial Doppler monitoring showed asymmetric mean flow velocities before improvement post hemicraniectomy for malignant middle

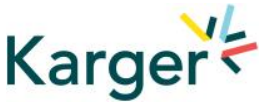

Kay Sin Tan

Division of Neurology, Department of Medicine

University of Malaya, Pantai Valley

Kuala Lumpur 50603 (Malaysia)

tanks18@hotmail.com or tanks_neuro@um.edu.my

Narayanaswamy Venketasubramanian

Raffles Neuroscience Centre, Raffles Hospita

585 North Bridge Road, \#09-00 Raffles Specialist Centre

Singapore 188770 (Singapore)

drnvramani@gmail.com 


\section{Case Reports in Neurology}

\begin{tabular}{l|l}
\hline Case Rep Neurol 2020;12:104-105 \\
\hline DOI: 10.1159/000509858 & $\begin{array}{l}\text { @ 2020 The Author(s). Published by S. Karger AG, Basel } \\
\text { www.karger.com/crn }\end{array}$ \\
\hline
\end{tabular}

Arjundas et al.: Stroke in Asia: Neurosonology in Neurocritical Care

cerebral artery territory infarction [4]. All the above cases emphasize the value of neurosonology in neurocritical care.

\section{Conflict of Interest Statement}

The authors have no conflicts of interest to declare.

\section{Funding Sources}

This journal supplement was funded by an unrestricted educational grant from Moleac Pte. Ltd.

\section{Author Contributions}

D. Arjundas completed the first draft and approved the final manuscript. J.D. Pandian, N. Venketasubramanian, and K.S. Tan reviewed the paper for content and clarity, provided critical feedback, and approved the final manuscript.

\section{References}

1 Idris MI, Tai SML, Tan CT, Tan KS. Streptococcus pneumoniae meningitis and intracranial vasculopathy: clinical correlation with improving transcranial Doppler hemodynamics. Case Rep Neurol. doi: 10.1159/ 000500950.

2 Venketasubramanian N, Taneja M, Choy D. Transcranial Doppler in the detection and management of arterial vasospasm after aneurysmal subarachnoid haemorrhage. Case Rep Neurol. doi: 10.1159/ 000504469

3 Venketasubramanian N, Tan AEH, Neo WT, Taneja M. Transcranial color-coded duplex ultrasound for assessing cerebrovascular reserve in intracranial dissection with aneurysm. Case Rep Neurol. doi: 10.1159/ 000505966

4 Barrozo HG, De Guzman MA, Navarro J, Venketasubramanian N. Asymmetric TCD findings in malignant MCA infarction, resolution after decompressive hemicraniectomy: a case report. Case Rep Neurol. doi: 10.1159/ 000508589 . 